\title{
WALTER JENS
}

\section{HOFMANNSTHAL}

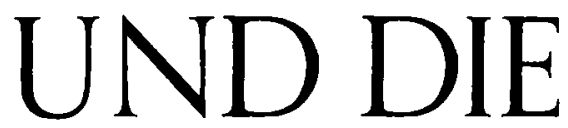

GRIECHEN

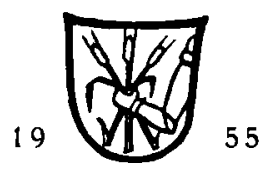

MAX NIEMEYER VERLAG - TUBINGEN 
Alle Rechte vorbehalten

Printed in Germany 1955

Druck: Graphische Betriebe W. Büxenstein G. M.B. H., Berlin 